\title{
THE PERIPHERAL VASCULAR RESPONSE TO EXERCISE IN THE HYPERTHYROID STATE
}

\author{
By DAVID I. ABRAMSON AND SIDNEY M. FIERST \\ (From the May Institute for Medical Research, The Jewish Hospital, Cincinnati) ${ }^{1}$
}

(Received for publication May 5, 1941)

In the hyperthyroid state, the various compensatory mechanisms ordinarily initiated by exercise may be modified by certain factors. Of interest in this respect is the finding that the resting cardiac output (1) and rate of peripheral blood flow to at least the forearm (2) and leg (3) are markedly augmented, thus suggesting that an increased amount of blood is necessary merely in maintaining the vegetative processes. Furthermore, since hyperthyroid patients require nearly twice as many calories as normal subjects to do a definite amount of exercise, the probability exists that they are inefficient in the performance of work (4).

In the present investigation, it was considered of interest to study the local circulatory response to exercise in hyperthyroidism, in order that some information might be gained as to the adequacy of the adaptive mechanisms in this state. For this purpose the venous occlusion plethysmographic method was utilized, since it afforded an opportunity of determining the changes in a small group of muscles.

\section{METHOD}

The study was conducted upon the forearm of 5 patients before and after subtotal thyroidectomy, the technique used in making the blood flow determinations being identical in all respects to that previously described (5). After 10 to 20 control readings had been obtained, the subject was required to perform a specified amount of work. This was accomplished by raising the pressure in a 5-gallon air-filled bottle to a definite level by means of ipsilateral manual compression of an ordinary sphygmomanometer bulb. The number of times the bulb was compressed, the period of exercise, and the height to which the pressure in the bottle was elevated were kept as constant as possible in all experiments performed on any one subject. Since the muscles utilized in this act were for the most part limited to the forearm encased in the plethysmograph, the changes in the blood flow readings could therefore be considered to represent the local circulatory reaction to the work.

Immediately upon completion of the task, forearm

1 Aided by the Samuel and Regina Kuhn Fund. blood flow determinations were obtained at 10 -second intervals during the first 3 minutes, and thereafter at onehalf minute periods until the blood flow returned to the previous resting level. In each instance, a graph was constructed from these figures, and by means of a planimeter the number of cc. of excess blood flow, over and beyond the previously determined average resting level, was calculated (Figure 1).

\section{RESULTS}

With one exception (L. M.), the number of cc. of excess local blood flow elicited by a period of work was definitely greater during the hyperthyroid state than after partial thyroidectomy (Table I). A correlation was readily apparent between the magnitude of the repayment and the level of basal metabolism (Figure 1). Similarly, the duration of the increased blood flow and the height of the single maximal response were significantly less following thyroidectomy (Table I). In the case of L. M., the reading which was not in agreement with the rest of the series was obtained 53 days postoperatively, at a time when signs suggestive of early hypothyroidism were present. In respect to the group as a whole, no definite relationship existed between the magnitude or duration of the blood flow repayment following exercise and the level of the resting blood flow at the time of the test (Table I, subjects J. L. and E. M.).

\section{DISCUSSION}

Since it was impossible to obtain accurate blood flow readings during the actual performance of exercise, the rate of blood flow in the period immediately following was studied instead. The rationale for this procedure is based on the assumption that, if the augmented circulation present during work is insufficient to meet entirely the increased demands of the tissues, a blood flow debt must be incurred; this, in turn, being repaid in the subsequent period of rest. The magnitude of the blood flow repayment would thus serve as 
an index of the circulatory response during the exercise. On such a basis, the foregoing results lend themselves to certain interpretations.

The finding of a much larger blood flow repayment in the hyperthyroid state than in the period following operation implies either that the compensatory mechanisms present during exercise are inadequate, that the blood flow requirement per unit of work is much greater than normal, or that both of these factors are operating. The fact that the cardiovascular system in the resting hyperthyroid patient is already functioning at a greater level of effort, analogous to that of a compensated heart with diminished reserve, suggests that the increased post-exercise response is due at least in part to inadequate adaptive mechanisms. Further, the finding that a definite relationship exists between the rate of metabolism and the magnitude of the blood flow repayment implies that the muscles of hyperthyroid patients require a greater than normal quantity of oxygen and food-stuffs in the performance of a specified amount of work. In other words, the local blood flow demands in exercise appear to be related to the metabolic level of the organism as a whole.

It would seem, therefore, that exercise places a severe load upon the circulation in hyperthyroidism, since a greater than normal blood flow requirement must be satisfied by a cardiovascular system already geared to a higher level of effort

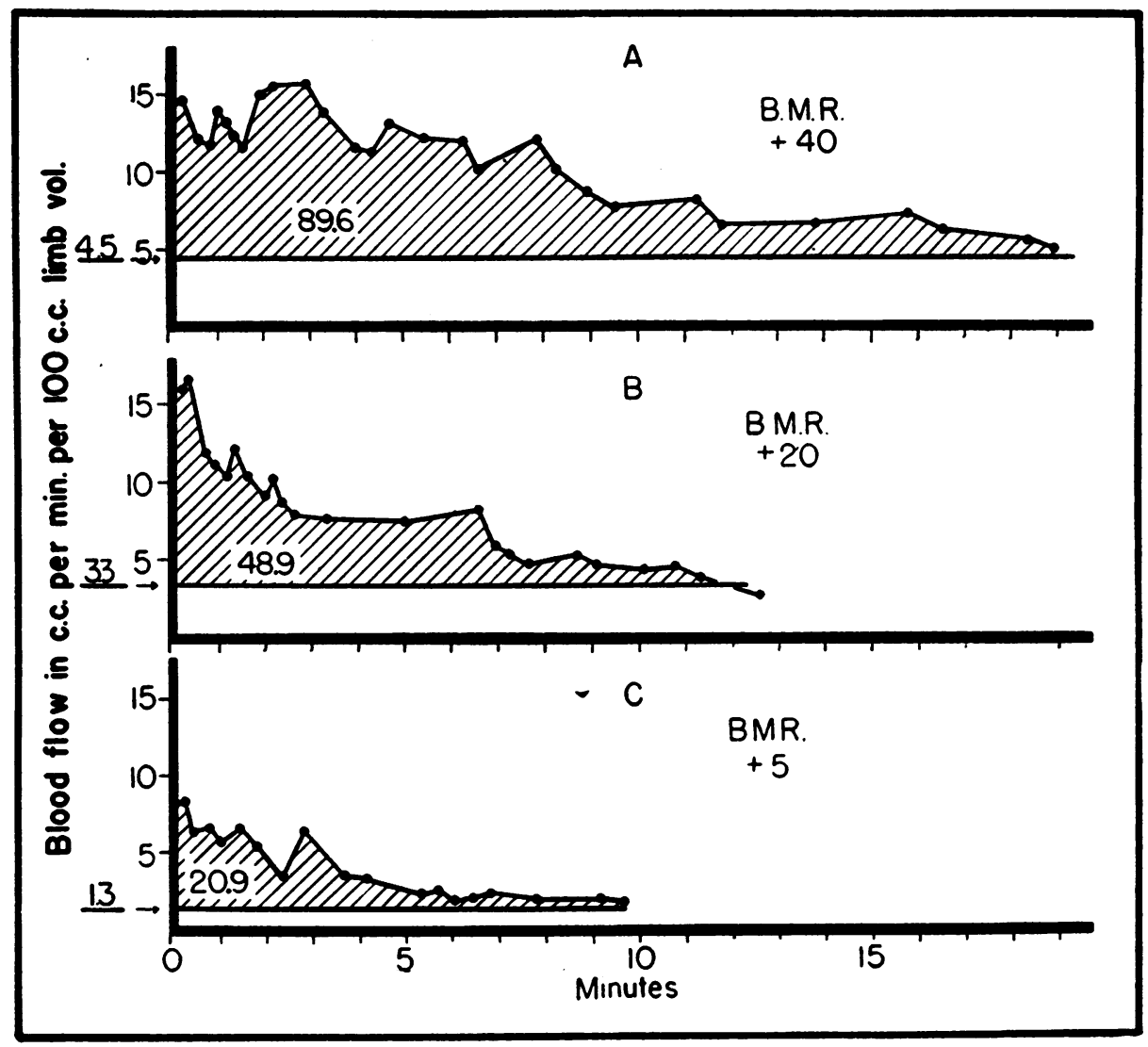

Fig. 1. Blood Flow Response in Forearm to a Specified Amount of Exercise SUBJECT E. M. (TABLE I)

A. 5 days before operation. Estimated basal level in period immediately following exercise, $4.5 \mathrm{cc}$. per minute per $100 \mathrm{cc}$. limb volume (equivalent to resting control blood flow before exercise). Excess blood flow elicited by the work, $89.6 \mathrm{cc}$. per $100 \mathrm{cc}$. limb volume. B. 4 days postoperatively. Estimated basal level, 3.3 cc. Excess blood flow, 48.9 cc. C. 28 days postoperatively. Estimated basal level, 1.3 cc. Excess blood flow, $20.9 \mathrm{cc}$. 
TABLE I

Blood flow response to exercise in the forearm

\begin{tabular}{|c|c|c|c|c|c|c|c|c|}
\hline Subject & Relationship to operation & Exercise* & Control flow & Repayment $\dagger$ & $\begin{array}{c}\text { Maximum } \\
\text { single } \\
\text { response } \\
\text { to } \\
\text { exercise }\end{array}$ & $\begin{array}{c}\text { Time of } \\
\text { maximum } \\
\text { response }\end{array}$ & $\begin{array}{l}\text { Total dura- } \\
\text { tion of } \\
\text { response }\end{array}$ & $\begin{array}{c}\text { Basal } \\
\text { metabolic } \\
\text { rate }\end{array}$ \\
\hline J. L. & $\begin{array}{c}\text { days } \\
2 \text { preoperative } \\
10 \text { postoperative }\end{array}$ & $\begin{array}{c}m m . H g \\
70 \\
70\end{array}$ & $\begin{array}{l}4.2 \\
4.1\end{array}$ & $\begin{array}{l}55.7 \\
26.0\end{array}$ & $\begin{array}{r}13.5 \\
8.6\end{array}$ & $\begin{array}{c}\text { seconds } \\
45 \\
30\end{array}$ & $\begin{array}{l}\text { minutes } \\
16 \\
14.5\end{array}$ & $\begin{array}{l}+24 \\
+12\end{array}$ \\
\hline M. B. & $\begin{array}{l}12 \text { preoperative } \\
35 \text { postoperative }\end{array}$ & $\begin{array}{l}40 \\
40\end{array}$ & $\begin{array}{l}3.6 \\
1.2\end{array}$ & $\begin{array}{l}33.0 \\
18.0\end{array}$ & $\begin{array}{r}10.7 \\
6.9\end{array}$ & $\begin{array}{l}30 \\
10\end{array}$ & $\begin{array}{l}19 \\
10\end{array}$ & $\begin{array}{r}+50 \\
0\end{array}$ \\
\hline E. M. & $\begin{array}{c}5 \text { preoperative } \\
4 \text { postoperative } \\
28 \text { postoperative }\end{array}$ & $\begin{array}{l}45 \\
45 \\
45\end{array}$ & $\begin{array}{l}4.5 \\
3.3 \\
1.3\end{array}$ & $\begin{array}{l}89.6 \\
48.9 \\
20.9\end{array}$ & $\begin{array}{r}15.1 \\
16.3 \\
8.2\end{array}$ & $\begin{array}{r}180 \\
20 \\
10\end{array}$ & $\begin{array}{l}19 \\
13 \\
10\end{array}$ & $\begin{array}{l}+40 \\
+20 \\
+5\end{array}$ \\
\hline J. P. & $\begin{array}{l}1 \text { preoperative } \\
4 \text { postoperative }\end{array}$ & $\begin{array}{l}60 \\
60\end{array}$ & $\begin{array}{l}5.3 \\
2.5\end{array}$ & $\begin{array}{l}42.7 \\
22.6\end{array}$ & $\begin{array}{r}11.8 \\
8.3\end{array}$ & $\begin{array}{l}40 \\
10\end{array}$ & $\begin{array}{l}20 \\
10\end{array}$ & $\begin{array}{l}+44 \\
+15\end{array}$ \\
\hline L. M. & $\begin{array}{r}7 \text { preoperative } \\
8 \text { postoperative } \\
53 \text { postoperative }\end{array}$ & $\begin{array}{l}50 \\
50 \\
50\end{array}$ & $\begin{array}{l}5.8 \\
4.2 \\
1.2\end{array}$ & $\begin{array}{l}42.7 \\
35.4 \\
41.9\end{array}$ & $\begin{array}{r}13.1 \\
10.5 \\
8.2\end{array}$ & $\begin{array}{r}100 \\
60 \\
25\end{array}$ & $\begin{array}{l}15 \\
15 \\
10\end{array}$ & $\begin{array}{l}+44 \\
+23 \\
-13\end{array}$ \\
\hline
\end{tabular}

* Height of pressure in 5-gallon bottle.

† Total number cc. excess blood flow per $100 \mathrm{cc}$. limb volume elicited by exercise.

Blood flow figures expressed in cc. per minute per $100 \mathrm{cc}$. limb volume.

during rest. In view of this, the fact that the hyperthyroid state is commonly associated with the symptoms of muscular weakness and fatigability is readily understandable.

\section{SUMMARY AND CONCLUSIONS}

1. The post-exercise blood flow repayment was generally found to be much greater in the hyperthyroid state than in the period following subtotal thyroidectomy.

2. A correlation was apparent between the level of oxygen consumption and the magnitude of the excess blood flow elicited by the exercise.

3. Exercise places a much greater load upon the circulation in hyperthyroidism than in the normal state.

\section{BIBLIOGRAPHY}

1. Davies, H. W., Meakins, J., and Sands, J., The influence of circulatory disturbances on the gaseous exchange of the blood. V. The blood gases and circulation rate in hyperthyroidism. Heart, 1924, $11,299$.

Fullerton, C. W., and Harrop, G. A., Jr., The cardiac output in hyperthyroidism. Bull. Johns Hopkins Hosp., 1930, 46, 203.

Liljestrand, G., and Stenström, N., Clinical studies on the work of the heart during rest. I. Blood flow and blood pressure in exophthalmic goitre. Acta med. Scandinav., 1925, 63, 99.

2. Abramson, D. I., and Fierst, S. M., Resting blood flow in the extremities in hyperthyroid subjects. Proc. Soc. Exper. Biol. and Med., 1941, 46, 39.

3. Abramson, D. I., and Fierst, S. M., Resting peripheral blood flow in the hyperthyroid state. Arch. Int. Med. (In press.)

4. Plummer, H. S., and Boothby, W. M., The cost of work in exophthalmic goiter. Am. J. Physiol., 1922, 63, 406.

5. Abramson, D. I., Zazeela, H., and Marrus, J., Plethysmographic studies of peripheral blood flow in man. I. Criteria for obtaining accurate plethysmographic data. Am. Heart J., 1939, 17, 194.

Idem, II. Physiologic factors affecting resting blood flow in the extremities. Ibid, 206.

Ferris, E. B., Jr., and Abramson, D. I., Description of a new plethysmograph. Ibid, 1940, 19, 233. 